\title{
In-Place Oil Shale Resources Underlying Federal Lands in the Piceance Basin, Western Colorado
}

\author{
Using a geologic-based assessment methodology, the U.S. Geological Survey estimated an in-place oil shale \\ resource of 1.07 trillion barrels under Federal mineral rights, or 70 percent of the total oil shale in place, in \\ the Piceance Basin, Colorado. More than 67 percent of the total oil shale in-place resource, or 1.027 trillion \\ barrels, is under Federal surface management.
}

\section{Introduction}

The U.S. Geological Survey (USGS) recently completed an assessment of in-place oil shale resources that underlie Federal lands in the Eocene Green River Formation in the Piceance Basin, western Colorado (fig. 1), incorporating the considerable amount of oil-yield data collected since a 1989 USGS in-place assessment. The new estimate of in-place oil in the basin is about 1.5 trillion barrels for all categories of mineral-rights ownership (Johnson and others, 2009), an increase of 50 percent over the previous assessment. Most of this increase is due to

1. Additional areas being assessed that previously had too little data for assessment purposes, and

2. New intervals being assessed.

Using geographic information systems (GIS) technology, several subsets of the 1.5-trillion barrels total were calculated by merging the oil shale resource data with Bureau of Land Management (BLM) surface and subsurface ownership files (BLM, 2009a, b). This resulted in an estimated Federal in-place resource of 1.07 trillion barrels (table 1). More than 67 percent of the total in-place resource, or 1.027 trillion barrels, is located under Federal lands. The map in figure 1 provides a general overview of Federal lands in the Piceance Basin; however, it should not be used to define title to any specific area, because of the complicated nature of surface and mineral estate ownership.

\section{Resources Underlying Federal Lands}

The entire oil shale interval in the Piceance Basin is subdivided into 17 "rich" and "lean" zones that were assessed separately (fig. 2). These zones are roughly time-stratigraphic units consisting of distinctive, laterally continuous sequences of oil shale beds that can be traced throughout much of the basin. More detailed analysis of the resource numbers was performed on the 17 zones than was done for the assessment in 2009.

Table 1 lists several subtotals of the 1.5 trillion barrels total that were calculated:

1. About 920 billion barrels ( 60 percent) exceed 15 gallons per ton (GPT),

2. About 352 billion barrels ( 23 percent) exceed $25 \mathrm{GPT}$, and

3. About 689 billion barrels ( 75 percent) of the 15 GPT total and about 285 billion barrels ( 81 percent) of the 25 GPT total are under Federal mineral (subsurface) ownership.
These 15 and 25 GPT estimates include only those areas where the weighted average of an entire zone exceeds those minimum cutoffs. In areas where the entire zone does not meet the minimum criteria, some oil shale intervals of significant thickness could exist within the zone that exceed these minimum cutoffs. For example, a $30-\mathrm{ft}$ interval within an oil shale zone might exceed 25 GPT, but if the entire zone averages less than 25 GPT, these resources are not included in the 15 and 25 GPT subtotals, although they might be exploited in the future.

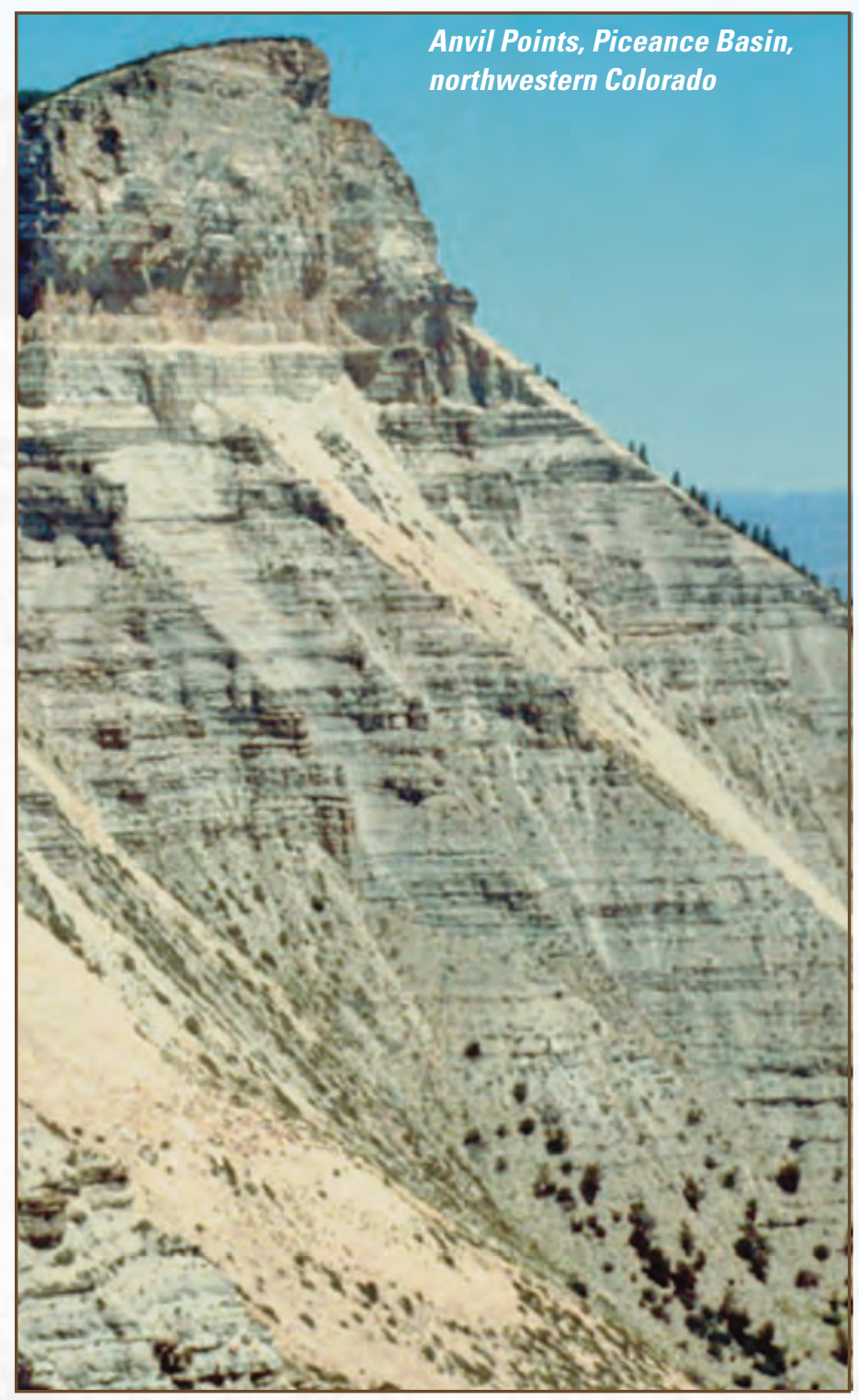




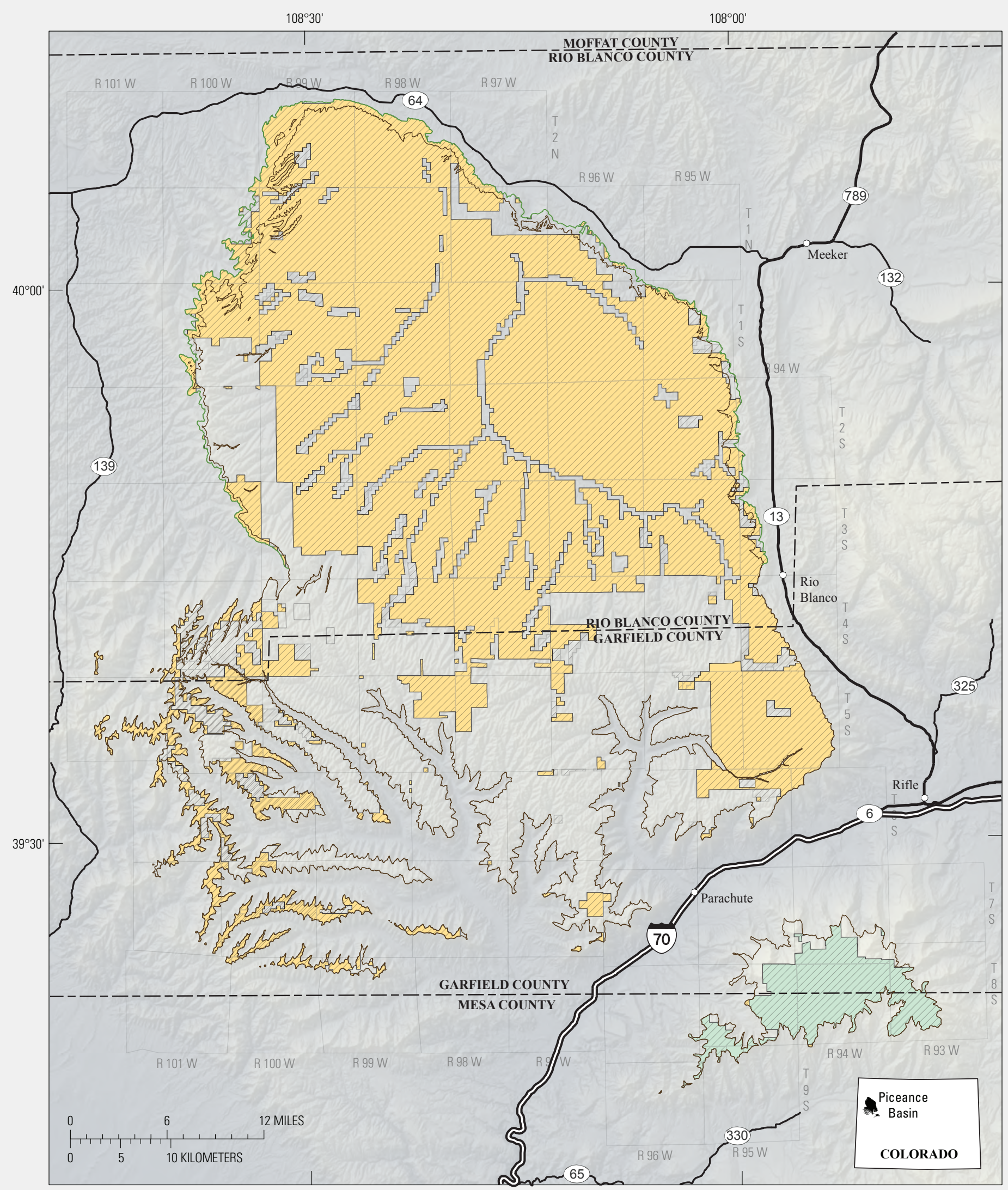

EXPLANATION

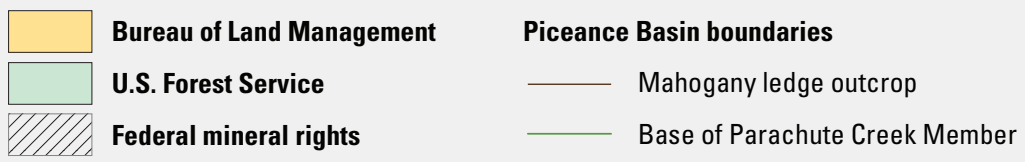

Figure 1. Map showing Federal surface management and Federal mineral rights of oil shale resources in the Eocene Green River Formation, Piceance Basin, Colorado. 
Table 1. Oil shale resources under Federally managed lands and under Federal mineral rights in the Piceance Basin, Colorado.

[Resource figures are in millions of barrels; resources are reported to four significant figures and may not equal the sum of the components, because of independent rounding; GPT, gallons per ton]

\begin{tabular}{|c|c|c|c|c|c|c|c|c|c|c|c|c|c|c|c|}
\hline \multirow[b]{3}{*}{$\begin{array}{l}\text { Oil shale } \\
\text { zone }\end{array}$} & \multicolumn{5}{|c|}{ All oil yields } & \multicolumn{5}{|c|}{ Oil yield of 15 gallons per ton or greater } & \multicolumn{5}{|c|}{ Oil yield of 25 gallons per ton or greater } \\
\hline & \multirow[b]{2}{*}{$\begin{array}{l}\text { Total oil } \\
\text { in place }\end{array}$} & \multicolumn{2}{|c|}{ Federal mineral } & \multicolumn{2}{|c|}{ Federal surface } & \multirow[b]{2}{*}{$\begin{array}{l}\text { Oil in } \\
\text { place }\end{array}$} & \multirow[b]{2}{*}{$\begin{array}{c}\text { As } \\
\text { percent } \\
\text { of total in } \\
\text { place }\end{array}$} & \multicolumn{3}{|c|}{ Federal mineral } & \multirow[b]{2}{*}{$\begin{array}{l}\text { Oil in } \\
\text { place }\end{array}$} & \multirow[b]{2}{*}{$\begin{array}{c}\text { As } \\
\text { percent } \\
\text { of total in } \\
\text { place }\end{array}$} & \multicolumn{3}{|c|}{ Federal mineral } \\
\hline & & $\begin{array}{l}\text { Oil in } \\
\text { place }\end{array}$ & $\begin{array}{c}\text { As } \\
\text { percent } \\
\text { of total } \\
\text { in place }\end{array}$ & $\begin{array}{l}\text { Oil in } \\
\text { place }\end{array}$ & $\begin{array}{c}\text { As } \\
\text { percent } \\
\text { of total in } \\
\text { place }\end{array}$ & & & $\begin{array}{l}\text { Oil in } \\
\text { place }\end{array}$ & $\begin{array}{c}\text { As } \\
\text { percent } \\
\text { of total in } \\
\text { place }\end{array}$ & $\begin{array}{c}\text { As percent } \\
\text { of } \\
\geq 15 \mathrm{GPT}\end{array}$ & & & $\begin{array}{l}\text { Oil in } \\
\text { place }\end{array}$ & $\begin{array}{c}\text { As } \\
\text { percent } \\
\text { of total in } \\
\text { place }\end{array}$ & $\begin{array}{c}\text { As percent } \\
\text { of } \\
\geq 25 \mathrm{GPT}\end{array}$ \\
\hline Bed 44 & 186,500 & 109,900 & 59 & 103,000 & 55 & 91,530 & 49 & 34,680 & 19 & 38 & & & & & \\
\hline A-groove & 6,283 & 4,394 & 70 & 4,178 & 66 & 92 & 1 & 88 & 1 & 96 & & & & & \\
\hline $\begin{array}{l}\text { Mahogany } \\
\text { zone }\end{array}$ & 191,700 & 129,600 & 68 & 124,200 & 65 & 181,000 & 94 & 119,900 & 63 & 66 & 108,300 & 56 & 70,090 & 37 & 65 \\
\hline B-groove & 7,819 & 5,463 & 70 & 5,256 & 67 & 158 & 2 & 132 & 2 & 83 & & & & & \\
\hline R-6 & 185,400 & 127,400 & 69 & 122,300 & 66 & 139,600 & 75 & 97,860 & 53 & 70 & 36,460 & 20 & 31,680 & 17 & 87 \\
\hline L-5 & 66,060 & 46,900 & 71 & 46,660 & 71 & 10,650 & 16 & 9,256 & 14 & 87 & & & & & \\
\hline $\mathrm{R}-5$ & 198,200 & 147,600 & 74 & 142,200 & 72 & 132,300 & 67 & 112,000 & 57 & 85 & 61,320 & 31 & 53,520 & 27 & 87 \\
\hline L-4 & 69,130 & 54,530 & 79 & 52,920 & 77 & 39,180 & 57 & 34,730 & 50 & 89 & 7,155 & 10 & 5,974 & 9 & 83 \\
\hline R-4 & 127,200 & 97,840 & 77 & 94,600 & 74 & 103,700 & 82 & 85,320 & 67 & 82 & 71,710 & 56 & 63,520 & 50 & 89 \\
\hline L-3 & 22,500 & 17,580 & 78 & 17,030 & 76 & 8,395 & 37 & 7,672 & 34 & 91 & 83 & $<1$ & 37 & $<1$ & 45 \\
\hline $\mathrm{R}-3$ & 68,080 & 56,480 & 83 & 55,040 & 81 & 56,150 & 82 & 50,150 & 74 & 89 & 27,240 & 40 & 24,790 & 36 & 91 \\
\hline L-2 & 24,220 & 19,860 & 82 & 19,290 & 80 & 9,643 & 40 & 8,843 & 37 & 92 & 146 & 1 & 89 & $<1$ & 61 \\
\hline $\mathrm{R}-2$ & 66,770 & 52,350 & 78 & 50,700 & 76 & 48,110 & 72 & 42,220 & 63 & 88 & 28,160 & 42 & 25,420 & 38 & 90 \\
\hline L-1 & 15,070 & 10,790 & 72 & 10,310 & 68 & 132 & 1 & 88 & 1 & 67 & 1 & $<1$ & & & \\
\hline R-1 & 195,400 & 124,900 & 64 & 118,300 & 61 & 94,480 & 48 & 81,770 & 42 & 87 & 10,990 & 6 & 9,705 & 5 & 88 \\
\hline L-0 & 8,265 & 6,023 & 73 & 5,799 & 70 & & & & & & & & & & \\
\hline R-0 & 83,420 & 58,240 & 70 & 55,600 & 67 & 5,040 & 6 & 4,293 & 5 & 85 & & & & & \\
\hline Total & $1,522,000$ & $1,070,000$ & 70 & $1,027,000$ & 67 & 920,100 & 60 & 689,000 & 45 & 75 & 351,600 & 23 & 284,800 & 19 & 81 \\
\hline
\end{tabular}




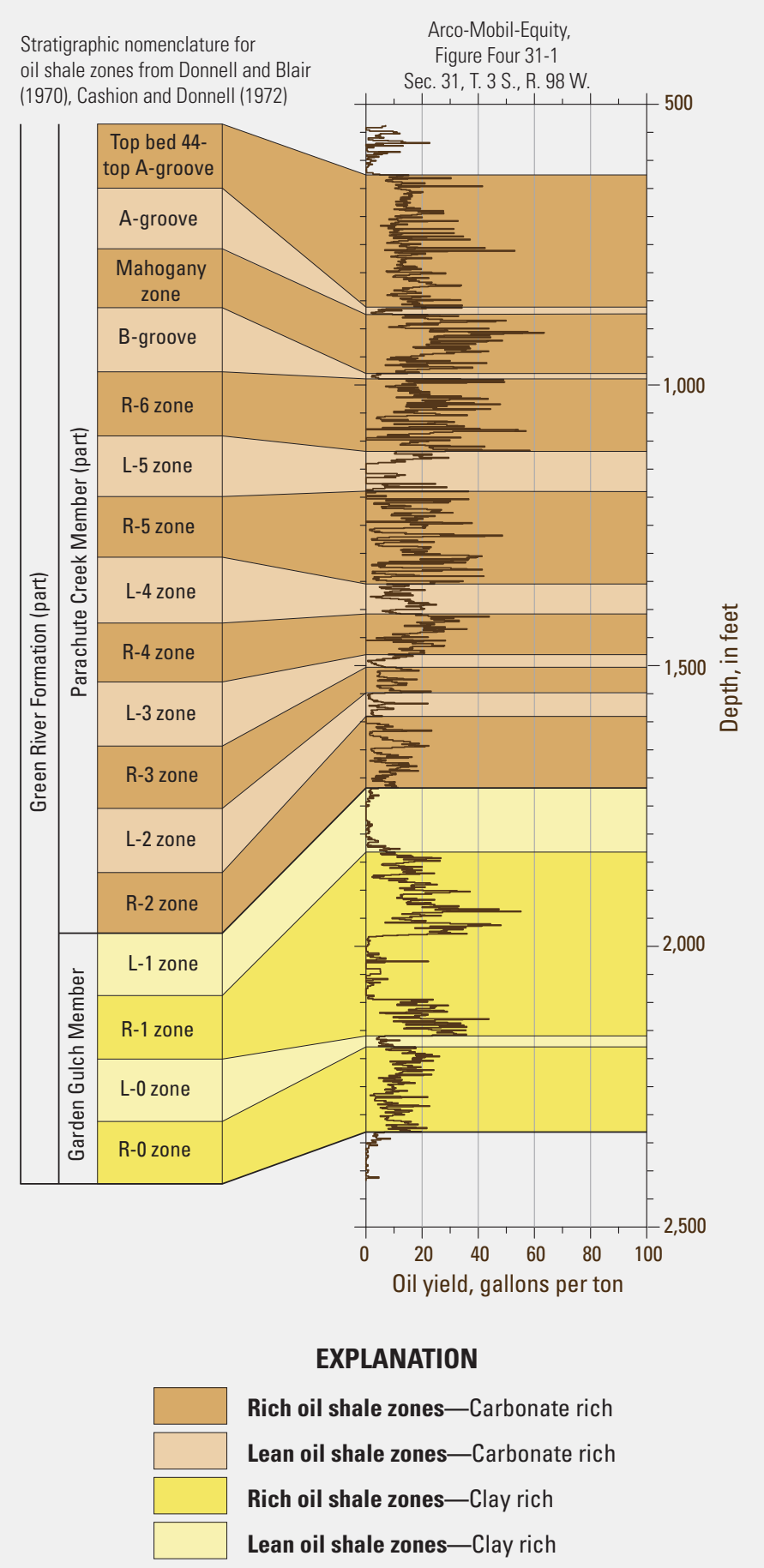

Figure 2. Chart showing oil yield in gallons per ton and the rich and lean oil shale zones in the Green River Formation assessed in this study.

\section{References Cited}

BLM (Bureau of Land Management), 2009a, Statewide land ownership (Colorado)_-lst_conflated_poly: Bureau of Land Management database, accessed April 13, 2010, at http://www.blm.gov/co/st/en/BLM_Programs/ geographical_sciences/gis/metadata.html.

BLM (Bureau of Land Management), 2009b, Statewide Federal mineral ownership (Colorado) _ co_fed_minerals: Bureau of Land Management database, accessed April 13, 2010, at http://www.blm.gov/co/st/en/BLM_Programs/ geographical_sciences/gis/metadata.html.

Cashion, W.B., and Donnell, J.R., 1972, Chart showing correlation of selected key units in the organic-rich sequence of the Green River Formation, Piceance Creek Basin, Colorado, and Uinta Basin, Utah: U.S. Geological Survey Oil and Gas Investigations Chart OC-65.

Donnell, J.R., and Blair, R.W., 1970, Resource appraisal of three rich oil-shale zones in the Green River Formation, Piceance Creek Basin, Colorado: Colorado School of Mines Quarterly, v. 65, p. 73-87.

Johnson, R.C., Mercier, T.J., Brownfield, M.E., Pantea, M.P., and Self, J.G., 2009, Assessment of in-place oil shale resources of the Green River Formation, Piceance Basin, western Colorado: U.S. Geological Survey Fact Sheet 2009-3012, 6 p.

\section{For Additional Information}

Supporting geologic studies of the oil shale-bearing units, assessment units, oil shale analysis, and the methodology used in assessing the oil shale resources in the Piceance Basin are in progress. Assessment results are available at the USGS Central Energy Science Center website at http://energy.cr.usgs.gov/ other/oil_shale/.

\section{Contact Information}

For further information contact

Tracey J. Mercier (tmercier@usgs.gov),

Ronald C. Johnson (rcjohnson@usgs.gov),

Michael E. Brownfield (mbrownfield@usgs.gov), or Jesse G. Self (jself@usgs.gov). 